\title{
ASSOCIATION OF “GREEN SPOT” AND DEFOLIATION TO Tenuipalpus heveae INCIDENCE AND CHEMICAL CONTROL SCREENING OF Hevea brasiliensis DISEASES
}

\author{
ASSOCIAÇÃO DA PRESENÇA DE “PINTA VERDE” E DESFOLHA COM \\ PRESENÇA DO ÁCARO Tenuipalpus heveae E AVALIAÇÃO DE FUNGICIDAS PARA \\ CONTROLE DE DOENÇAS EM PAINÉIS DE SERINGUEIRA Hevea brasiliensis
}

\section{Fernando Cezar JULIATTI ${ }^{1}$; Héloi Inácio da FONSECA ${ }^{2}$; Maria Angélica Barcelos CARNEIRO ${ }^{3}$; Breno Cezar Marinho JULIATTI ${ }^{4}$; Lucas dos Santos NASCIMENTO}

1. Professor Titular, Instituto de Ciências Agrárias, Universidade Federal de Uberlândia- UFU, Pesquisador 1D do CNPq, Uberlândia, MG, Brasil; 2. Eldorado Agro-Florestal, Uberlândia, MG, Brasil; 3. Consultor em cultivos de Seringueira, Especialista em Proteção de Plantas pelo Instituto Agronômico de Campinas - IAC, Campinas, SP e Gerente de Pesquisa da Empresa JuliAgro B, G \&P. 4. juliatti@ufu.br. 5. Bolsista de Iniciação Científica, Curso de Agronomia - UFU-Uberlândia, Campus Umuarama.

\begin{abstract}
According to IBGE data, in 2016, Brazil produced closer to 56 thousand hectares of rubber tree generating a total latex production of 315.62 tons in commercial areas and 1.6 thousand tons in native forests. But this growth in crop production is related to the raise of economic losses generated by foliar and bark (panel) diseases caused by Phytophthora spp, Colletotrichum sp., Lasiodiplodia spp., Colletotrichum sp., Ceratocystis fimbriata, Microcyclus ulei (leaf blight) and the leaf anomaly that we call here as "Green Spot". Also, due to the tapping method and the incisions or "injuries" made in this process, opportunistic pathogens can usually infect and end up growing in the bark. This type of infection that is also difficult to control with the adoption of chemical fungicides, can create additional damage to the rubber panels. Pathogens such as Oidium heveae, C. gloeosporioides (anthracnosis), Phomopsis sp. and Phytophthora spp. were identified in $42 \%$ of the areas of growers or farms. Treatments T3- (thiophanate-methyl (350 g.ha ${ }^{-1}$ active ingredient) and T4- (metiram (1.75 kg.ha ${ }^{-1}$ active ingredient)) were superior against rot diseases in the bark of rubber trees. It was described for the first time the anomaly of the green spot associated to the Tenuipalpus heveae mite in $65 \%$ of the samples and had its etiology confirmed by artificial inoculation in rubber tree seedlings. In the USP-ESALq, Dr. Kitajima, E., did not confirm the presence of rhabdovirus-like particles common to tenuipalpids that transmit the virus in coffee and citrus (nuclear and cytoplasmic viruses).
\end{abstract}

KEYWORDS: Green spot. Rubber trees. Pest and diseases. Mites.

\section{INTRODUCTION}

Extraction of latex from rubber tree (Hevea brasiliensis (Wild, ex A Juss) Muell. Arg., began around the eighteenth century in Brazil colony, initially the extraction of fluids where in selected trees at the middle of the native vegetation (Amazon). The first commercial crops were installed inside colonies after higher profits and economic return (ALVARENGA; CARMO, 2014). At the nineteenth century, the process of vulcanization was discovered, and the largest source of raw materials to produce finished rubber is provided by natural rubber, making Brazil the largest producer and exporter. This process made several industries and banks move to the northern region of Brazil. However, with increasing demand for rubber, the expansion of commercial crops and the emergence of synthetic rubber, positioned a risk to the national production in Brazil (ALVARENGA; CARMO, 2014). In this scenario, Henry Ford invested in larger infrastructure and skilled workforce to expand the production of rubber inside the Amazonian forest. However, this system was devastated by an epidemic caused by Microcyclus ulei (P. Henn), the leaf blight agent, this disease destroyed several production areas, expanding to other tropical areas and pushing the crop to regions (southern Asia) with better conditions of production and lower exposition to the disease. (FURTADO, 2014).

Nowadays, Brazil is not independent in the production of natural rubber, because expansion in production area is limited by diseases development and due to the biological imbalance in the system of rubber production. Currently, the main difficulties faced by producers are to monitor, manage and identify the appearance of possible pathogens after the tapping process. According to IBGE data, in 2016, Brazil registered a rubber tree area of 156,06 thousand hectares, of which 146.4 hectares were harvested, generating a total latex production of 315.62 tons in commercial areas. 


\section{CONTENTS}

\section{Main phytossanitary problems}

Microcyclus ulei also called leaf blight is known worldwide as one of the most important diseases for the rubber tree. But the expansion of production areas allowed higher incidence of foliar diseases developed by Phytophthora spp, Colletotrichum sp., Alternaria spp., Oidium sp. and green spot. Gasparotto \& Pereira (2013) cited fungi pathologies in rubber trees barks panels like Lasiodiplodia spp., Colletotrichum sp., Ceratocystis fimbriata, Erythricium salmonicolor and Phytophthora spp., and related the presence of leaf blight to a raising incidence of other opportunistic fungi. Due to the fluid collection in the bark vessel, the process of "tapping" causes several injuries to the trunk and facilitates facilitate the infection of pathogen, that usually are difficult to control (GONÇALVES, VALIM and SALDANHA, 2013). The chemical control of diseases is restricted to a few group of fungicides, thiophanate-methyl and chlorothalonil, both usually are used on a large scale.

At the last decade, pest problems were limited to ants' and caterpillars (Erinnyis ello).
Currently insects such as whitefly, thrips, scale insects, crickets, and bedbug (Leptopharsa heveae) and especially mites Calacarus heveae and Tenuipalpus heveae are promoting massive damage to rubber trees (ALVARENGA; CARMO, 2014).

\section{Phytosanitary survey in rubber trees nursery at Triangulo Mineiro, Brazil}

Samples of leaves, bark of trunks, roots and soil were collected at five farms and four nurseries generating nine locations in several municipality (Araguari, Uberlândia, Uberaba and Prata), and were inspected for pests and diseases of fungal and nematode etiology. The analyses were made at two different labs, the LAMIP and LANEM, both localized at the Federal University of Uberlândia. The study was conducted during two seasons 20112013, during the period of two mite spices infestation, the T. heveae and $C$. heveae and in all places they were identified. Also, the incidence of one species of stink bug Leptopharsa heveae (42\%) and species of the cochineal Pinaspis sp (65\%) were observed in rubber tree seedlings inside the nurseries. The incidence and distribution of pests is reported in Figure 1.

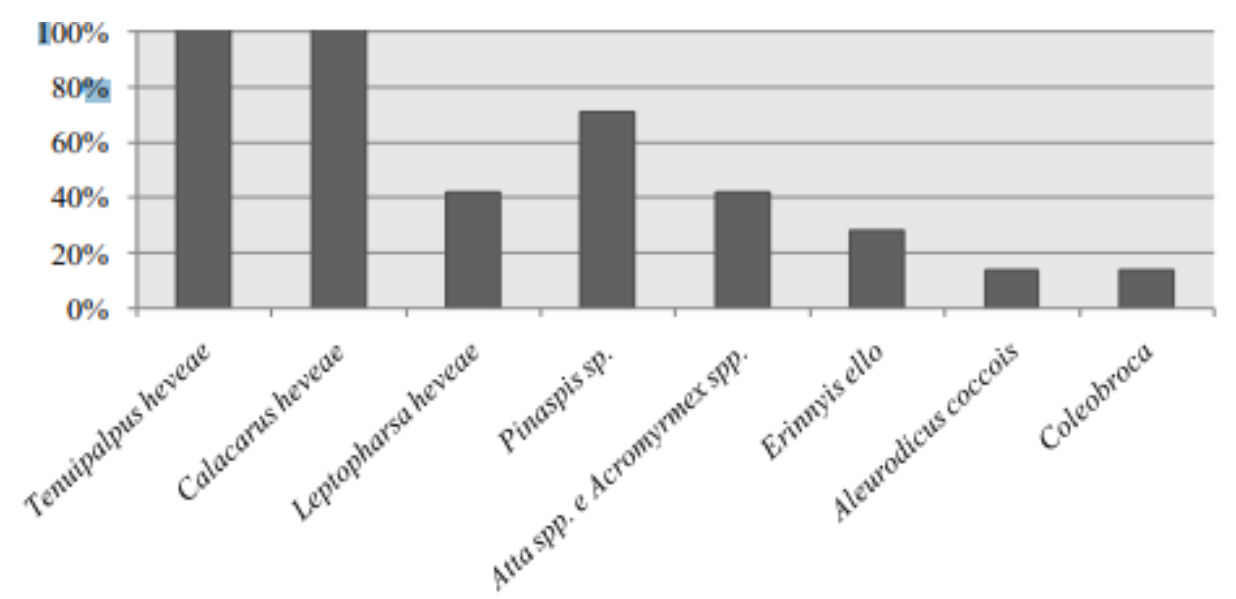

Figure 1. Incidence of pests on field areas in Triângulo Mineiro region of Minas Gerais State

The higher distribution of mite species in this work, could be explained by the short life cycle of mites be of difficult control by farmers. Nowadays, the Ministries of Agriculture Livestock and Supply (MAPA) registered few products to control the plagues inside the crops. Also, problems such as mite resistant to chemical compounds, is reported with regular frequency in producer areas. Another important factor is the technology used in the application of pesticides. Due to the extension of production areas and a denser plant canopy, adapted equipment is required for higher coverage of pesticide spray. But usually this type of equipment is expensive and impractical in several farms. Also, mite resistant to intense use of acaricides is becoming an issue in several regions, the spray of copper-based products is selecting and pressing mite populations to mutate.

The stink bug $L$. heveae, is considered an important rubber tree pest and usually is related to negative economic impact in latex production. With the recent addition of biological control to the system (parasitic fungi), producers are able to effectively manage the populations and sustained its 
geographic distribution. In relation to other pests, our result showed a lower distribution in comparison, but this issue still deserves attention, since they are mostly found in nurseries and their spread with relative easiness through contaminated seedlings. Leaf diseases such as leaf blight, was identified in five of the seven locations visited (71\%), accompanied by the symptom of the "Green Spot" anomaly. Other disease agents such as $O$. heveae, C. gloeosporioides, Phomopsis sp. and Phytophthora spp. were identified in almost half of grower's areas or farms (42\%), (Figure 2).

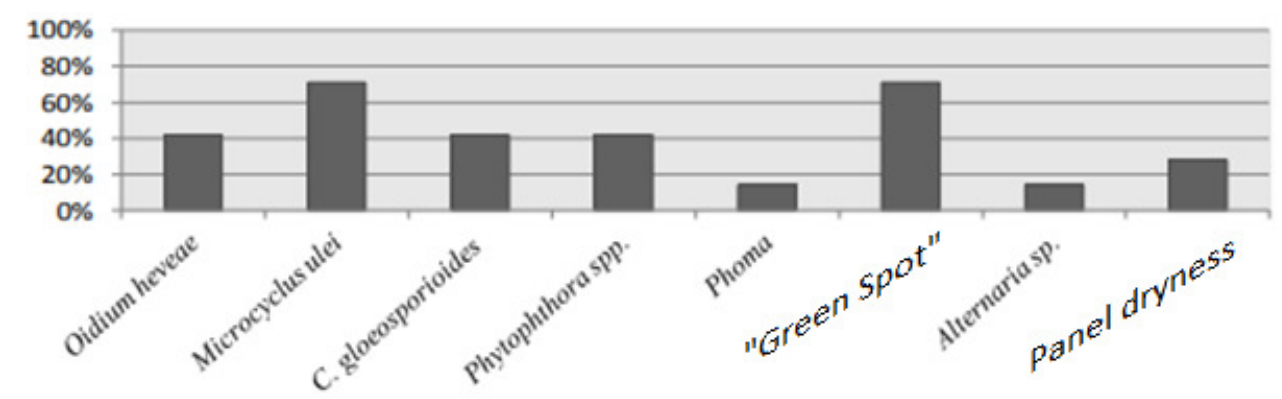

Figure 2. Incidence (\%) of rubber tree diseases in Triângulo Mineiro region of Minas Gerais state.

Leaf blight had a significant presence in the Triângulo Mineiro region, even being considered by MAPA an area without disease occurrence. After seedling transfer to field, leaf blight cannot complete its cycle due to the beginning of dry season. However, it deserves attention in nursery areas where the micro climate is ideal for its development due to constant irrigation and higher density of rubber plants. Other pathogens were detected such as downy mildew and anthracnosis and its management usually is made by preventive and curative pesticides. Soil analyzes had negative results for nematodes. In the State of São Paulo, a survey that covered 54 counties and 64 nurseries, resulted in the presence of Meloidogyne exigua and
Pratylenchus brachyurus in $82 \%$ and $74 \%$ respectively of the total sites sampled (SOARES et al, 2012). Therefore, due to the proximity of this region to the state of Minas Gerais, certification of nurseries and cultural practices are required to lesser or avoid dissemination. The report of mite incidence is associated with the appearance of red mite symptoms (anaphylae) and "green spot".

During the identification of the mite in the samples, it was noticed that the symptom of the "green spot" was present in $71 \%$ of the production areas. So, with this information (Table 1) we can ensure that, there is a higher probability of association between "green spot" presence with the incidence of red mite (T. heveae).

Table 1. Presence of Tenuipalpus heveae and green spot in Hevea brasiliensis production areas, localized in the region of Triângulo Mineiro during seasons 2011 to 2013.

\begin{tabular}{cccc}
\hline & & T. heveae & "Green spot" \\
\hline \multirow{2}{*}{ Field Samples } & Ouro Branco & + & + \\
& Una Heveplan & - & - \\
Adult plants & Don Pablo & - & + \\
& Hevea & + & + \\
Nursery & Copaiba & + & + \\
Samples & Amparo & + & + \\
& Alvorada & + & + \\
Seedlings & Ouro Branco & - & + \\
\hline
\end{tabular}

Symptoms similar to this anomaly have been reported in citrus (leprosis - Brevipalpus phoenicis Geijskes), passion fruit (Green Pigeon Brevipalpus phoenicis Geijskes) and (Ring spot Brevipalpus phoenicis Geijskes). In previous studies, it was detected transmission and detection of the nuclear rabid virus in cell citoplasm. The mites that transmit those viruses are from the Tenuipalpidae family and were detected in the rubber tree samples. Juliatti and Carneiro (2013), infested and confined rubber trees seddlings with mites of the $T$. heveae species with plastic bags 
(cages) for 60 days and obtained evolution and development of "Green spot" symptoms (figure 3). In a similar experiment, the previous authors attempted the transmission by another mite, the Calacarus heveae and didn't had success in visualization of symptoms.

Leaves samples (freshly collected in the field) and infected fresh shoots with typical symptoms of rhabdoviruses, were conditioned in boxes with dry ice and sent to the transmission electron microscopy (TEM) sector of the ESALq -
USP to confirm the possible viral etiology. The analyzes performed by Dr. Kitajima, and his team did not confirm the presence of rhabdovirus-like particles common to tenuipalpids transmission coffee and citrus (nuclear and cytoplasmic viruses). The symptoms (mosaic) or green patches occurs due to mite toxins being injected in leaves and branches changing plant physiology. It is suggested to improve the technique of viral analysis via TEM with modifications to definitively discard the viral etiology in this anomaly (figure 3).

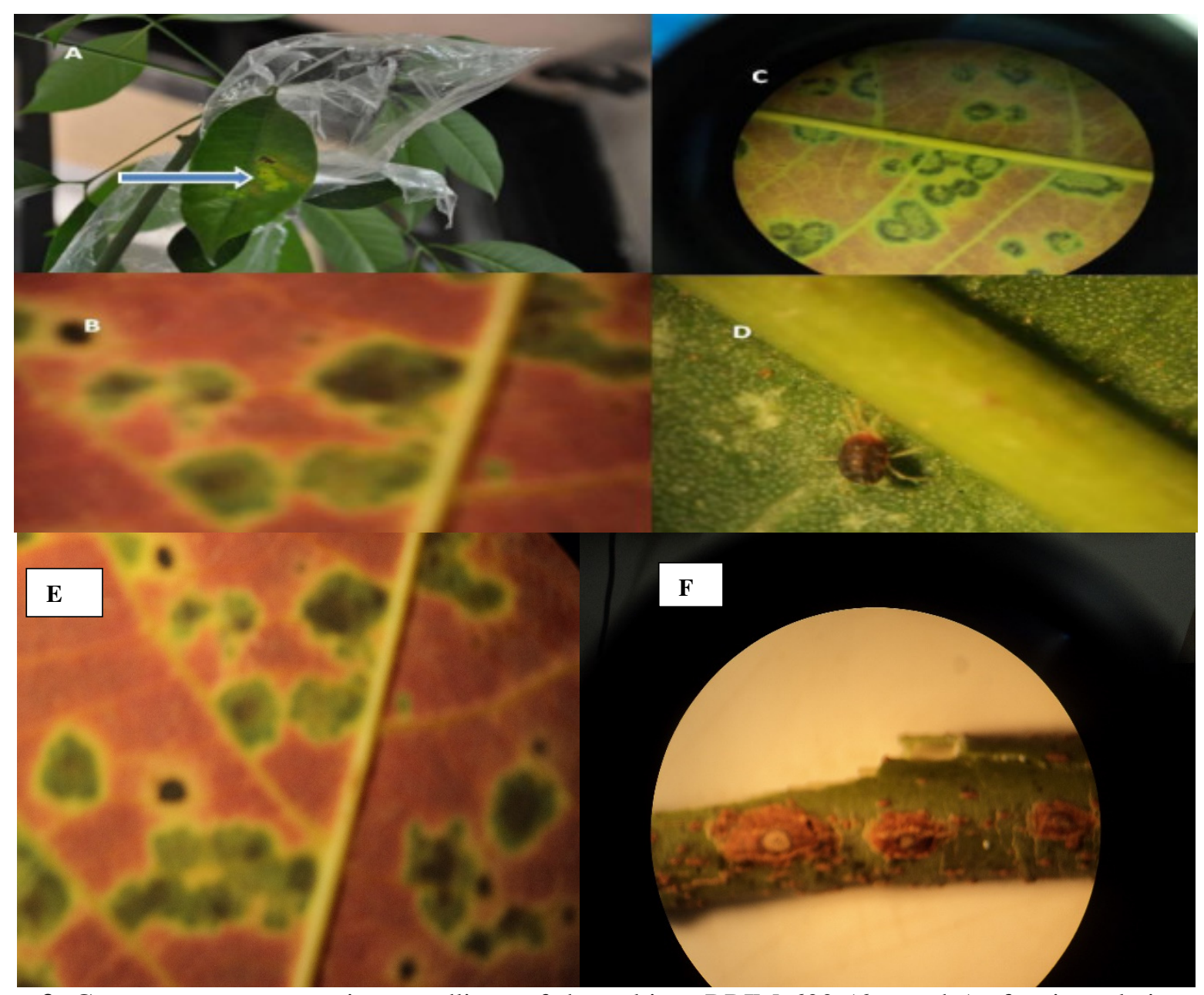

Figure 3. Green spot symptoms into seedlings of the cultivar RRIM 600 (6 months) after inoculation of the Tenuipalpus heveae (red mite) by plastic cages on young leaves A-Artificial inoculation in seedlings plants (6 months)), B and C- Symptom in leaves of RRIM 600 trees, D- Mite Tenuipalpus heveae (Tenuipalpidae) (Red mite) "probable" the main vector of the disease or anomaly. ESymptoms on infected leaves ("like mosaic") and F- Symptoms in branches.

Vieira (2013), associated the virus mosaic anomaly or "Green spot" with the presence of Calacarus heveae and not from Tenuipalpus heveae infestation. The author also related the symptom with other types of potyvirus. However, there is no work with this hypothesis on the Triângulo Mineiro region. Thus, it is concluded that the distribution of M. ulei and "Green spot" is uniform in the region.
Mites such as T. heveae, and C. heveae can have rapid dissemination and generates higher level of damage. The incidence of anomalies such as Grean Spot may be related to the presence of $T$. heveae, even without confirmation of the association between mite and pathogen (virus). The green spot occurred in $71 \%$ of rubber trees samples, collected in nurseries at Triângulo Mineiro. The authors have 
attributed the anomaly to the presence of the mite Calacarus heveae and were successful in its respective control with the use of sulfur and synthetic. Those sprays were realized between December through April (VIEIRA; GOMES, E.C; FIGUEIRA, 2006).

\section{Efficacy of fungicides in rubber trees's panels diseases}

The experiment was installed in the property Sítio Copaíba, inside the county of Uberaba, MG (19 $16^{\prime} 754^{\prime \prime} \mathrm{S}$ da $\left.47^{\circ} 90^{\prime} 454^{\prime \prime} \mathrm{W}\right)$. The experiment design was (DBC) with four blocks per treatment, each repetition was constituted by 25 trees ( six years old) of the RIMM 600 clone. The clone was in the first year of latex production and extraction. The treatments consisted in T1- (thiophanate-methyl + chlorothalonil)- (320 and $800 \mathrm{~g} / \mathrm{ha}$ of i.a respectively), T2- (pyraclostrobin + fluxapiroxade) (83.25 and $41.75 \mathrm{~g} / \mathrm{ha}$ of i.a respectively), T3 (thiophanate-methyl (350 g / ha of i.a respectively), T4 - (metiram (1.75 kg / ha i.a) and T5- Check (without fungicide brush). The analysis were made in the phytopathology laboratory of Federal University of Uberlandia (LAMIP). To identify injured areas by fungi, tissue samples were collected from panels in the bark. The figure 4 shows the fungicide brush on rubber trees.
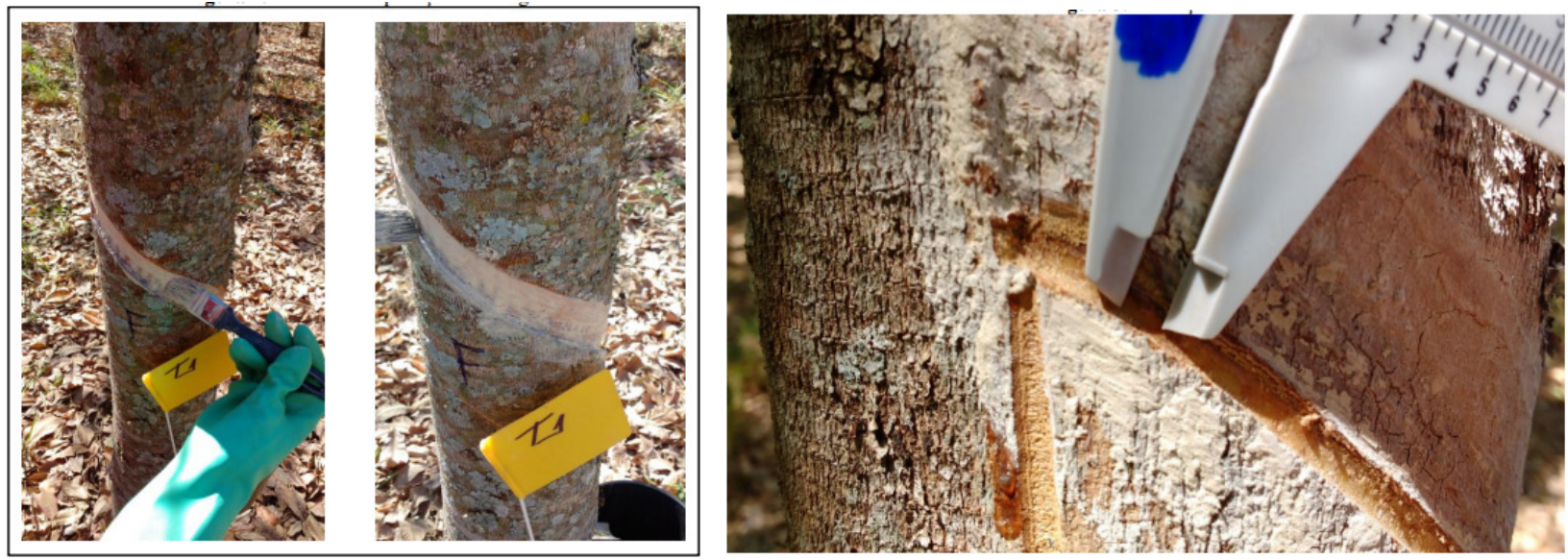

Figure 4. Fungicide being brush on rubber trees panels of RIMM 600 (six years old) and the evaluation of the lesions with a caliper rule.

The evaluations were performed briefly after the first latex extraction (injury) and continued during 30 days without any more injuries in the tapped panel. The evaluations were number of lesions (figure 4), lesion area (caliper rule measuring injured area in the panel - severity) and latex productivity. The fungi isolated in the samples were a complex characterized by, Colletotrichum gloeosporioides, Fusarium verticillioides and Fusarium semitectum. Producers usually report anthracnosis as the only pathogen on the tapped panel (Colletotrichum gloeosporioides or Colletotrichum acutatum), but this diagnosis is usually wrong, and accurate evaluations by clinics usually appoints infection of Fusarium sp.

Table 2. Treatments and its effect on the complex of panel diseases in Rubber Trees.

\begin{tabular}{cccc}
\hline Treatment & $\begin{array}{c}\text { Number } \\
\text { of lesions }\end{array}$ & $\begin{array}{c}\text { Lesion } \\
\text { area } \\
\left(\mathbf{m m}^{2}\right)\end{array}$ & $\begin{array}{c}\text { Latex } \\
\text { productivity } \\
\left.\text { (Kg.ha1 }^{-1}\right)\end{array}$ \\
\hline T1 & $25.2 \mathrm{a} 1 \mathrm{a} 2$ & $828.2 \mathrm{a} 2$ & $517.2 \mathrm{a} 1$ \\
$\mathrm{~T} 2$ & $29.2 \mathrm{a} 2$ & $284.7 \mathrm{a} 1 \mathrm{a} 2$ & $618.7 \mathrm{a} 1$ \\
$\mathrm{~T} 3$ & $15.5 \mathrm{a} 1$ & $131.5 \mathrm{a} 1$ & $537.5 \mathrm{a} 1$ \\
$\mathrm{~T} 4$ & $14.2 \mathrm{a} 1$ & $103.7 \mathrm{a} 1$ & $515.0 \mathrm{a} 1$ \\
Check & $18.5 \mathrm{a} 2$ & $166.2 \mathrm{a} 1$ & $481.2 \mathrm{a} 1$ \\
\hline
\end{tabular}

There is significant difference $(\mathrm{p}<0.05)$ between treatments for number of lesions, lesion area and latex productivity (Table 2). Treatments 3 and 4 had a superior effect in the control of the fungi complex resulting in lower panel rot (T3(thiophanate-methyl (350 g / ha active ingredient), T4-(metiram (1.75 kg / ha active ingredient). In 2012, Gasparotto and Pereira described 
chlorothalonil (isophthalonitrile) or the mixture of thiophanate-methyl $\quad+\quad$ chlorothalonil (isophthalonitrile + Benzimidazole) as a chemical control option for rubber trees panel diseases. Alvarenga and Carmo in 2014 also suggested the rotation of fungicides of the previous chemical group with propiconazole and tebuconazole to improve control of tapped panel disease. Treatment 1 (thiophanate-methyl + chlorothalonil) is recommended by several works at the literatures to control panel diseases, but in our experiment it didn't differ significantly of the results showed by the check. The results obtained in the experiment, demonstrate that there is not a direct relationship between number of lesions with lesion area and productivity. We can conclude that several factors in the of soil / plant / environment can interact and results in different latex productivity in rubber trees. In view of these results, we can also report that the treatment T4- Metiram, presented smaller number and area of lesions in comparison with the check, based in lesion or necrotic area generated by the complex of panel rot diseases.

\section{ACKNOWLEDGMENTS}

Thanks CAPES, CNPq and FAPEMIG Foundation for the financial supports.

RESUMO: Segundo dados do IBGE, em 2016, o Brasil registrou uma área cultivada de 156,06 mil hectares, dos quais 146,4 mil hectares foram colhidos, promovendo uma produção total de 315,62 toneladas em lavouras comerciais. Já a exploração em áreas de vegetação natural, resultou em 1,6 mil toneladas de látex e coágulo. Microcyclus ulei também chamado de Mal-de-Folhas é conhecida mundialmente como a doença mais grave da seringueira, mas a intensificação do cultivo permitiu prejuízos econômicos promovidos por doenças foliares como Phytophthora spp, Colletotrichum sp., Alternaria spp., Oidium sp. Entre outros, além da anomalia de Pinta Verde. No tocante às doenças de sapé, são citadas as patologias fúngicas nos painéis Lasiodiplodia spp., Colletotrichum sp., Ceratocystis fimbriata, Erythricium salmonicolor e Phytophthora spp.,. Muitos patógenos permitem a entrada nas lesões de outros fungos oportunistas. Devido ao modo de exploração (corte) causar lesões no tronco que facilitam a inoculação de patógenos principalmente através de instrumentos de sangramento, causando danos nos painéis de seringueiras e são patógenos de difícil controle e poucos resultados significativos com o uso de fungicidas ou produtos químicos. Os patógenos, como Oidium heveae, C. gloeosporioides (antracnose), Phomopsis sp. e Phytophthora spp. foram identificados em $42 \%$ das áreas de produtores ou fazendas. Os tratamentos 3 e 4 foram os melhores do controle dos fungos e esta podridão de painel nas seringueiras (T3- (tiofanato-metílico(350 g / ha ingrediente ativo), T4- (metiram (1,75 kg / ha ingrediente ativo).Foi

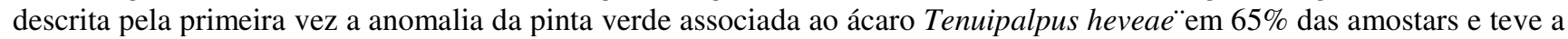
sua etiologia confirmada por inoculação artificial em mudas de seringueira. Análises em microscopia eletrônica realizadas na USP-S-ESALq pelo Dr. Kitajima, E., não confirmaram a presença de partículas tipo rabdovírus comum aos tenuipalpídeos que transmitem a virose em cafeeiro e citros (vírus tipo nuclear e citoplasmático).

PALAVRAS-CHAVE: Pinta verde. Seringueira. Pragas e doenças. ácaros.

\section{REFERENCES}

ALVARENGA, A. P.; CARMO, C. A. F. S. Seringueira. 2. ed. Viçosa: Epamig, 2014. 1065p FURTADO, E. L. Doenças das folhas e do caule da seringueira. In: Alvarenga, A. P; Carmo, C. A. F. S. C. Seringueira. Viçosa: EPAMIG Zona da Mata, 2014. 2 ed, cap.12, p. 595-632.

GASPAROTTO, LUADIR; PEREIRA, J. C. R. Doenças da seringueira no Brasil. $2^{\mathrm{a}}$ edição. Brasília: Embrapa, 2012. GONÇALVES, R. COELHO; VALIM, J. H.; SALDANHA, D. Estudo de Prevalência de Fungos em Painel de Sangria de Seringueira no Acre. Universidade Federal do Acre. 2013. Disponível em www.alice.cnptia.embrapa.br/bitstream/doc/976115/1/24846.pdf. Acessado em: 04/12/2017.

JULIATTI, F. C; CARNEIRO, M. A. Transmissão experimental da anomalia da pinta verde da seringueira com adultos do ácaro Tenuipalpus heveae Baker. In: Congresso Brasileiro de Heveicultura, 3. 2013. Guarapari. Anais... Incaper: Guarapari, 2013. 1 CD-ROM. 
SISTEMA IBGE DE RECUPERAÇÃO AUTOMÁTICA - SIDRA. Tabela 5457 - Área plantada ou destinada à colheita, área colhida, quantidade produzida, rendimento médio e valor da produção das lavouras temporárias e permanentes. Disponível em: https://sidra.ibge.gov.br/tabela/5457\#resultado. Acesso em 13/12/2017.

SISTEMA IBGE DE RECUPERAÇÃO AUTOMÁTICA - SIDRA. Produção da Extração Vegetal e da Silvicultura. Disponível em: https://sidra.ibge.gov.br/pesquisa/pevs/quadros/brasil/2016 . Acesso em 13/12/2017. SOARES, P. L. M.; SANTOS, J. M.; PAES, V. S. Ocorrência de nematoides em amostras de solo e raízes coletadas em viveiros de mudas de seringueira mo Estado de São Paulo. Disponível em Acesso em 15 de out. 2012 VIEIRA, M. R. et al. Manual ilustrado de pragas e doenças em seringueira. 2013. Disponível em: Acesso em: 30 de ago.2013.

VIEIRA, M. R.; MARTINS, G. L. M.; SCALOPPI JÚNIOR, E. J. Resistência de clones de seringueira à infestação por ácaros. Bragantia, Campinas, v. 72, n. 4, p. 367-372, 2013. http://dx.doi.org/10.1590/brag.2013.044.

VIEIRA, M. R.; GOMES, E. C.; FIGUEIRA, J. C. Controle Químico de Calacarus heveae Feres (Acari: Eriophyidae) em Seringueira.Bioassay,, SEB, v. 1, n. 9, p. 1-7, 2006. 